УДК 811.161.2?36:654.19(045)

\title{
ВАРІАНТНІСТЬ У РОДОВІЙ КАТЕГОРИЗАЦІї ІМЕННИКІВ (на матеріалі мовлення сучасного українського телебачення)
}

\author{
ЗАЙЦЕВА О. М.
}

аспірант

Київський національний лінгвістичний університет helenzaitseva@i.ua

\begin{abstract}
У статті здійснена спроба проаналізувати іменники, які зазнали варіантних змін граматичної категорії роду в межах сучасних мовних тенденцій, що реалізуються нині в мовленні українського телебачення, також окреслено деякі причини появи таких тенденцій, частотність уживання таких іменників. Крім того, подано короткий огляд кодифікації в словниках певних іменникових одиниць, що варіюються морфологічними показниками граматичного роду. У ході аналізу з'ясовано, що носії телевізійного мовлення все частіше обирають морфолого-граматичний варіант на користь питомого відповідника граматичної категорії роду, нерідко й ревіталізованого або ж діалектного слова чи рідковживаного. Формально-граматичні показники категорії роду іменника сучасного телемововжитку зміщуються, реалізуючись у таких модифікаціях: чоловічий рід $\rightarrow$ жіночий рід, жіночий рід $\rightarrow$ чоловічий рід.
\end{abstract}

Ключові слова: варіантність, мовна тенденція, телемовлення, граматична категорія роду, іменник, чоловічий рід, жіночий рід.

\section{VARIABILITY IN GENDER CATEGORISATION OF NOUNS (in contemporary Ukrainian TV speech)}

\author{
ZAITSEVA Olena Mykolayivna \\ PhD student \\ Kyiv National Linguistic University \\ helenzaitseva@i.ua
}

Introduction. Nowadays the language of modern television broadcasts' speeches is more and more in the focus of linguistic study. Special interest of given paper is comprised by the variability in gender categorization of nouns as it occurs in speeches of Ukrainian TV programs anchorpersons. The object of the paper is the choice of nouns in modern TV speech, that is distinguished due to the variability of grammatical category of the gender of nouns ways of realization.

Purpose of the article is to analyze the nouns that have suffered changes in the grammatical category of gender within the current language trends being implemented in the broadcast of Ukrainian television. In addition, the aim is to outline some of the reasons for the emergence of such tendencies, the relative use of these nouns, the degree of codification in modern lexicographic sources.

Methods of research. The research is grounded on descriptive method, the method of empiric analysis, immediate constituents' analysis, and contextual analysis.

Results. Studying the language used in contemporary Ukrainian TV speeches convincingly demonstrated how formal-grammatical indicators of the category of gender of nouns in modern telecommunication vary (shift), implemented in the following modifications: male genius $\rightarrow$ female genus, female genus $\rightarrow$ male genus. In addition, the review of codification in the dictionaries of the analyzed noun units shows that variational changes in the morphology of the noun and in particular, in its morphological and grammatical categories nowadays cause not only the dislocation of the current linguistic norm, but also tend to change the morphological norms. 
Conclusion. Analyzing the language used in speeches of informative and entertaining Ukrainian TV programs' anchorpersons, we have concluded that they prefer to choose different grammatical variations in favor of a specific counterpart to the grammatical category of the gender, often a revitalized or dialectal word used.

Keywords: variability, linguistic tendency, television broadcasting, grammatical category of the gender, noun.

Формулювання проблеми та обгрунтування актуальності ії розв'язання. У сучасній українській мові іменник виявляє тенденцію до мовної варіантності, в основі якої, як зазначає М.Д. Карп’юк, “лежить співіснування паралельних засобів мови, які мають спільне лінгвістичне, у тому числі й граматичне значення, але різняться сферою поширення” (1978). Ця особливість іменника виявляється на всіх мовних рівнях: лексичному, синтаксичному, словотвірному. Відбито їі і в морфологічній системі мові. Вважаємо актуальним дослідження варіантності граматичної категорії роду іменника, оскільки варіантні зміни в морфології іменника, зокрема, в його морфолого-граматичних категоріях, нині зумовлюють не лише розхитування чинної мовної норми, а й виявляють тенденцію до зміни морфологічних норм. Особливо це стосується динаміки граматичних категорій зі змінними іменниковими формами, до яких і належить категорія роду, що потребує стратифікації як “класифікаційна самостійна морфологічна категорія, яка в типових виявах має диференційовану сукупність афіксів (флексій і суфіксів) для свого вираження, поєднує семантико-граматичний зміст назв істот на грунті їхнього стосунку до біологічної статі або недорослості та формально-граматичний зміст назв неістот і складається з грамем чоловічого, жіночого і середнього роду" (Вихованець, Городенська, 2004).

Мета цісї статті - виявити й дослідити варіанти норми в межах граматичної категорії роду іменників, що реалізовані в українському телевізійному мовленні, з'ясувати причини їх виникнення, відносну частотну уживаність у мові й уплив на мовний узус і норму.

Аналіз останніх публікацій. Категорію роду іменника в українській мові досліджувало чимало відомих лінгвістів, зокрема: І.Р. Вихованець і К.Г. Городенська (2004), Є.А. Карпіловська (2007), І.Г. Матвіяс (1974), В.В. Поставний (1974), Родніна (1963) та ін. Однак їхні праці стосуються переважно теоретичних аспектів морфології іменника. Нашу ж увагу привертає насамперед реалізація в межах норми варіантних форм граматичної категорії роду іменника в живому мовленні і в мовленні українського телевізійного соціуму.

Мову телебачення з погляду нормативності вивчали українські мовознавці О.О. Тараненко (2015), О.А. Стишов (2005), С.А. Карпіловська (2007) та ін. У засобах масової інформації нормативність, як відомо, має бути основним критерієм вибору мовного варіанта. Журналісти, ведучі сучасних українських телепрограм повинні дотримуватися норм української літературної мови. Проте демократизація суспільства посприяла розхитуванню норм українського телевізійного мовлення, зокрема й у сфері морфологічних категорій іменника, а саме категорії роду. І.Г. Матвіяс (1974) свого часу зазначав, що “хитання щодо роду в іменниках іншомовного походження буває зумовлене різними причинами. Інколи воно може відбивати стан неунормованості, подвійності в самій мові - джерелі чи посереднику або (частіше) таке хитання - наслідок різних джерел і шляхів запозичення" (с. 29).

Варіантні вияви категорії роду іменника ми зафіксували в мовленні українських найбільш рейтингових телеканалів. Матеріал дібрано 3 телеефіру різних сучасних телепередач, насамперед інформаційних, аналітичних, науково-публіцистичних: “Вікна” на СТБ, “Факти” та “Факти тижня” на ICTV, “ТCH” та “ТCH тижня” на каналі “Студія 1+1”, “Новини” на каналі “112 Україна”, блоки новин на телевізійних каналах NewsOne, Eспресо TV, 24 канал та деяких інших. Динамічні варіантні морфолого-граматичні процеси, відтворювані в мові системно, послідовно й частотно, безумовно, знаходять свою реалізацію у мовних тенденціях. Про це раніше зазначала Г.І. Лиса (2015), наголошуючи, що “динаміка родової категоризації іменника в сучасній 
українській мові виявляється в розвитку деяких тенденцій та їх лексикографічного закріплення" (с. 287). Термін мовна тенденція тлумачимо за Є.А. Карпіловською (2007), яка трактує його “як позначення основного поняття, що відбиває динаміку мови в певний відрізок часу та в певних умовах іiі функціонування” (с. 3), покликаючись на праці німецького дослідника сучасних слов'янських мов К. Гутшмідта. Учений трактує тенденцію як “спрямування мовних процесів або змін, що відбуваються у формі закріплення інновацій чи усунення застарілих мовних одиниць, конструкцій, норм” (Карпіловська, 2007, с. 3). Сама ж дослідниця сучасних тенденцій характеризує цю дефініцію як “перевагу у вияві тих чи інших мовних змін, стійкості певних типів інновацій” (Карпіловська, 2007, с. 3).

Якщо ж уживані в мові явища, що відповідають певній тенденції, стають настільки частотними й відтворюваними повсякчас мовцями в живомовній практиці, їх кодифікують в лексикографічних виданнях і поступово вони закріплюються мовним узусом. Щодо варіантних (дублетних) форм у межах морфолого-граматичної парадигми, то очевидним $є$ те, що один 3 варіантів (найменш уживаний) відходить на периферію мови, інший - найбільш уживаний домінує в мовному узусі носіїв мови. Про такі переміщення варіантів неодноразово зазначали В.А. Чабаненко, Л.І. Кучеренко, О.А. Стишов, В.В. Поставний, Н.Ф. Клименко та інші науковці.

Виклад основного матеріалу й обгрунтування отриманих результатів дослідження. Однією з тенденцій сучасного телемовлення $є$ варіювання родових грамем іменників-неістот, а саме: уживання грамеми жіночого роду замість усталеної грамеми чоловічого роду й навпаки, хоч одразу зазначимо, що перший варіант дещо частотніший у мовленні телебачення. Іменникиназви неістот мають своєрідний формально-граматичний план вираження. Вони членуються за родами суто формально, адже не мають відмінностей з погляду семантико-граматичного змісту. Як зазначає I.P. Вихованець (2004), “їхня родова диференціація семантично не мотивована. Категорії роду, у яку об’єднуються такі іменники, притаманні в такому випадку ознаки формальних класів, які і дають підстави вважати, що з-поміж іменникових категорій рід займає периферійне місце, перебуває в тій периферійній площині, де перетинаються морфологічні категорії і формальні класи" (с. 85). Надалі ж ітиметься про такі варіантні пари іменників, що репрезентують собою загальні назви неістот: метод - метода, зал - зала, філіал - філія і под. Очевидним $є$ те, що закріплена морфологічна норма таких парних, переважно запозичених номінацій окреслена грамемою чоловічого роду: метод, зал, філіал. У цьому контексті слушними $\epsilon$ зауваги К.С. Горбачевича (1971), який на матеріалі російської мови довів, що закріплення певного граматичного роду в запозиченні відбувається зазвичай шляхом підрівнювання до роду слів у рідній мові (у певному сенсі аналогійних запозиченому) (с. 159). Учений також вважав положення про те, що форма роду в запозиченого слова цілком визначається родом цього слова в мові-джерелі, не завжди правильним. У цьому питанні дослідник покликається на праці А.В. Суперанської, яка зазначила, що “не завжди можна безпомилково визначити джерело запозичення і не всі мови, з яких ми черпаємо запозичення, мають категорію роду” (с. 159). Саме тому відсутність у певній мові категорії роду означає відсутність у ній граматичного протиставлення іменників за родостатевою ознакою, зауважував в енциклопедичній статті В.М. Русанівський (2000).

Отже, з огляду на те, що в оформленні іншомовних слів українською мовою діє принцип мовної аналогії, цілком логічно, що в мові донині домінантною була форма чоловічого роду, наприклад, слово метод, а не метода (жіночого роду). К.С. Горбачевич (1971) свого часу зазначав, що коливання граматичного роду характерні для 1) питомих слів; 2) запозичень 3 м'якою основою; 3) запозичень 3 твердою основою на приголосний (с. 155). До останніх і належать такі запозичення, як метод - метода і подібні.

У мові українського телебачення останнім часом нерідко спостерігаємо тенденцію до вибору на користь форми жіночого роду за наявності в мові форм чоловічого роду, тобто реалізовано 
видозміну чоловічий рід $\rightarrow$ жіночий рід. Серед фрагментів мововжитку журналістів та телеведучих зафіксовано уживання грамеми жіночого роду (з відповідною флексією -а (-я)) на місці традиційної форми чоловічого роду з нульовим закінченням: це моя метода (112 Україна, Студія 112 Live, 17.02.2016 р., 13.15, ведучий); відкрили три нових філії (Студія 1+1, ТСН тижня, 29.10.2017 р., 19.30, журналістка); відсуває ліжко, висуває комоду (Студія 1+1, ТСН тижня, 28.10.2017 р., 19.30, журналістка); друга компонента полягає в тому, щзо ... (112 Україна, Студія 112 Live, 01.04.2017 p., 11.15, гість студії). У телемовленні трапляються й не дуже частотні утворення з формальним показником жіночого роду (із флексією -ія) і певним емоційностилістичним відтінком у семантиці: карнавалія триває (Студія 1+1, ТСН, 12.02.2011, 19.30, ведуча, а також у графічному відтворенні). Уживання цієї одиниці в значенні загальної назви, очевидно, перенесено з інноваційної номінації - власної назви, як-от: триває 5-й ювілейний бал “Карнавалія”(Студія 1+1, ТСН, 12.02.2011, 19.30, ведуча). Відзначимо, що варіантна форма комода (жіночий рід) є досить давньою, іï фіксує Словник української мови Б.Д. Грінченка (1908, с. 276), хоча походить вона з французької мови за російського та польського посередництва (ЕСУМ, 1982-1989, с. 539); слово метода в СУМі (1970-1980) марковане як книжне, застаріле. Про варіанти із таким маркуванням В.В. Поставний (1974) писав: “Нормативні джерела досить часто засвідчують функціональну спроможність членів варіантної пари, позначаючи менше вживані варіанти помітками “застаріле”, “діалектне”, “рідковживане”, “розмовне” тощо (с. 36). Про це раніше зазначав і Ю. Шевельов (2002), засуджуючи диктаторське вилучення українських питомих форм за часів домінування російської мовної політики.

Отже, як бачимо, форми одного граматичного роду трансформуються в інший, при цьому відповідно змінюється формально-граматичний показник категорії роду: грамема чоловічого роду змінюється на грамему жіночого. Та окремо слід виділити ще й інший вид варіантної модифікації, що відбувається в межах одного граматичного роду, натомість диференціюється лише закінчення іменників, як, наприклад, спостерігаємо у варіантній парі роль - роля: ви одразу увійшли в ролю (СТБ, “Танцюють всі”, 11.11.2015 р., 15.45, ведуча).

Серед репрезентантів найуживанішої варіантної модифікації роду іменника (чоловічий рід $\rightarrow$ жіночий рід), найбільшу частотність у сучасному українському мовленні виявляє іменникова пара зал $\rightarrow$ зала. Варто відзначити, що зала кодифіковано в академічних фундаментальних словниках як паралельне основному загальновживаному зал, зокрема у Словнику української мови в 11-ти томах (СУМ, 1970-1980, с. 179), а також у сучасних і деяких новітніх лексикографічних виданнях, зокрема в Сучасному орфографічному словнику української мови (180 тис. слів) (СОСум, 2009, с. 283), у Словнику української мови в 20-ти томах (СУМ, 2013). 3 огляду на це варіант зала є загальновживаним, нормативним (його значення абсолютно ідентичне значенню зал “те саме, що зал” (СУМ, 1970-1980), проте в реальному мовленні цю одиницю донедавна вживали рідко. У сучасному ж (новітньому) телевізійному мововжитку родову форму зала демонструють такі фрагменти: для тих, хто любить поїсти без свідків - окрема зала (Студія 1+1, ТСН, 22.09.2017 р., 19.30, журналістка); у изій спортивній залі (ICTV, Надзвичайні новини, 29.09.2017р., 09.20, журналістка); а це репетиція концерту в актовій залі (24 канал, Новини, 01.10.2016 р., 21.00, журналістка); кілька хвилин i зала наповнюється (112 Україна, Студія 112 Live, 27.04.2017 p., 06.15, журналістка); перша зала, яка призначена для показу (Студія 1+1, “Аргумент-кіно”, 13.11.2016 р., 01.30, гостя студії); такий результат розбірок за приміщення гральної зали (ICTV, Факти тижня, 04.02.2018р., 18.45, журналістка); відбулася інспекція в бенкетній залі ресторану (Студія 1+1, “Новий інспектор Фреймут. Міста", 06.11.2016 р., 12.05, ведуча).

Як видно з наведених прикладів, пошуки нових, оригінальних виражальних засобів у мові змушують мовців вдаватися до варіантних (варіантних рідковживаних, варіантних діалектних чи варіантних давніх) формально-граматичних дублетних виявів. Активізація форм зала, метода, 
роля, комода, фільма, санаторія і под. свідчить про ревіталізацію (відродження) орфоепічних й орфографічних норм часів українізації кінця 20-х років ХX ст. К.С. Горбачевич (1971) констатує, що “живомовна українська практика й узус тих часів відбивали таку вимовну норму як паралельну” (с. 156). Принагідно зазначимо, що ці форми були характерними для української мови й раніше, на межі XIX і XX ст., зокрема фіксуємо їх у мові й творах українських письменників указаного періоду. Пор. в оповіданні М. Коцюбинського (1979) “Дебют”: “Потому бігла у хати робити лад. Перевертала усе в буфеті, висувала шухляди комоди $і$ так ї лишала, бралась за щітку, щзоб замітати підлоги, $і$ коли за нею бігли збентежені слуги, вона їх відсувала рішуче: - Hi, ні, спочиньте трохи. У вас і так багато діла” (с. 261); “Яка сила пхає мене в безодню і каже: грай ролю - іменно, іменно, я розумію, щзо се лиш гра! - $i$ дає мені певність, щзо не покину гри і не обірву ролі, аж поки не доведу їх до самого краю, які б результати не були; щзо так само, як досі, я буду втискати в душу чужої людини свою істоту, накидати свої бажання, засівать своє “я" (с. 266). Іменники комода, роля і под. утворюють, як правило, варіантні пари. І. Г. Матвіяс (1974) стверджує, що “велика кількість таких варіантних пар припадає на запозичення з грецької, латинської, французької, німецької та інших мов: візит - візита, зал - зала, комод - комода" (с. 2).

У сучасному мовленні до тенденційного варіантного вживання можна віднести й протилежну модифікацію: жіночий рід $\rightarrow$ чоловічий рід. Причому така варіантна модифікація притаманна більшою мірою питомим іменникам, не запозиченим. Зокрема, особливою частотністю відзначається одиниця сховок, яка разом із схованка репрезентує спільну кореневу морфему, що, на нашу думку, є носієм тієї самої семи, об'єднаної певним категоріальним значенням. Словотвірна організація слів сховок і схованка має спільну дієслівну етимологію: сховок

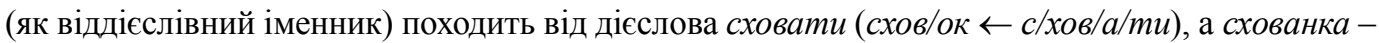
від дієприкметника схований, який у свою чергу утворений від дієслова сховати (cхова/н/к/a $\leftarrow$ схова/н/uй $\leftarrow c / x о в / a / m и)(У Р C C, 1995$, с. 230). Таким чином, за морфологічно-граматичними показниками і на основі спільних лексичних значень, що кодифіковані в академічному 11-томному СУМі, одиниця сховок є паралельною і, певною мірою, варіантною до схованка. Пор.: Схованка, и, ж. "Місце, де можна сховатися від кого-, чого-небудь, знайти притулок, захист; схов, укриття" (СУМ, 1970-1980, с. 890). Сховок, вку, ч. “Місце, де можна сховатися, укритися, захиститися від кого-, чого-небудь; схованка, укриття” (12, с. 892). Як бачимо, слово сховок кодифіковане як рівнозначне зі схованка за семантикою, навіть без маркування рідковживане, однак у реальному мовленні воно траплялося зрідка, переважно у певному діалектному ареалі, зокрема у волинських говірках. У мовленні ж централізованого (не регіонального!) українського телебачення цю діалектну одиницю почали вживати передусім для відображення регіонального мовного колориту і здебільшого на позначення "укриття, схрону для бійців колишньої УПА”. У мововжитку журналістів та телеведучих інформаційних, пізнавальних, аналітичних телепередач сучасного синхронного періоду констатуємо саме такі (вузькорегіональні, колоритні) реалізації цього слова: сховки почали діяти ще в 30-х роках (24 канал, Пізнавальні програми: наші, 01.01.2017 р., 11.15, голос ведучого за кадром); сховки були по всій Волині (24 канал, Пізнавальні програми: наші, 01.01.2017 р., 11.15, голос ведучого за кадром); виявивши сховок, радянські війська ... (24 канал, Пізнавальні програми: наші, 01.01.2017 p., 11.15, голос ведучого за кадром). Натомість нині в мовленні телепередач не історичного спрямування (тобто не про бійців УПА), а досить різного за жанром сховок уживається саме як варіант морфолого-граматичної норми схованка (за аналогією до спадокспадщина), наприклад: неприємний запах привів до страшного сховку (ICTV, Надзвичайні новини, 04.12.2017 р., 19.20, ведучий). Також зафіксовано уживання одиниці сховок у мові мультиплікаційних фільмів на дитячому телеканалі Plus-Plus: iдеальний сховок пустельного nipama (Plus-Plus, м/ф “Джейк і пірати з Небувалії”, 23.09.2017p., 10.20, голос за кадром); він 
провів весь день у сховку (Plus-Plus, м/ф “Ніндзяго”, 11.06.2017 р., 21.30, голос за кадром); кажу тобі: сховку немає (Plus-Plus, м/ф “Ліло і Стіч”, 19.03.2017 р., 15.45, голос за кадром). Відповідно варіант сховок закріплено й орфографічною нормою. Сучасний орфографічний словник української мови подає обидва слова: сховок і схованка (СОСум, 2009, с. 856). Отже, нині спостерігаємо тенденцію до зміни морфологічної норми в цьому слові в сучасному медіавжитку: грамема жіночого роду поступається грамемі чоловічого роду.

Подібної морфологічної модифікації в мові телебачення зазнав іменник мотузок: грамема чоловічого роду із нульовою флексією усе частіше фігурує на місці узуальної грамеми жіночого роду із закінченням -a: $y$ мене $\epsilon$ довгий мотузок (Plus-Plus, м/ф "Блиск і монстромашини", 29.08.2017 p., 09.00, голос за кадром); перевіримо, чи може вона [акула] перекусити довгий мотузок (Plus-Plus, м/ф “Блиск і монстромашини”, 29.08 .2017 р., 09.00, голос за кадром). СУМ не маркує одиницю мотузок як діалектну, хоч вона поширеніша в мові південно-західного наріччя. 11-томне академічне видання одиниці мотузок $і$ мотузка за семантикою ставить в один ряд як паралельні, навіть без відтінка значення. Пор.: Мотузок, зка, ч. "Зісуканий із прядива виріб для зв'язування або прив'язування кого-, чого-небудь" (СУМ, 1970-1980, c. 813). Мотузка, и, ж. "Те саме, що мотузок” (СУМ, 1970-1980, с. 813).

Іменник повінь в українській мові має чітко фіксоване значення граматичного роду жіночого. Формою жіночого роду марковано цю одиницю і в Словнику української мови Б.Д. Грінченка (1908, с. 222). Однак у мові сучасних теленовинних блоків ії реалізовано з флексією чоловічого роду, що вказує на порушення морфологічної мовної норми: відзначився черговим повенем (112 Україна, Новини, 03.05.2017 р., 12.00, ведуча); повінь у Греиії забрав життя n'ятнадияти людей (24 канал, Новини, 16.11.2017 р., 12.00, ведуча).

Як морфологічний варіант (або просто дублет) можна трактувати варіантну питому пару cycid - cyciдa, оскільки диференційна ознака тут виражена лише граматично - варіантними флексіями (чоловічий рід - нульова флексія, жіночий рід - флексія -а). Наприклад: О.Савельєв cycida (СТБ, Вікна, 31.05.2017 р., 18.00, у графічному відтворенні). Одиниця сусіда, хоч і має формальні ознаки жіночого роду, однак за семантичним наповненням належить до спільного роду, чоловічого й жіночого. Зазначимо, що цей іменник фіксовано не лише в СУМі (із значенням “те саме, що сусід і сусідка" (СУМ, 1970-1980, с. 856), він представлений і в Словнику Б.Д. Грінченка, у якому його значення витлумачено майже так само, як у СУМI: Те саме, що 1) Сусід. 2) Підсусідок. 3) Сосъдка (14, с. 281). Сучасний орфографічний словник української мови фіксує його як лексему чоловічого й жіночого роду (СОСум, 2009, с. 854).

У сучасній лінгвістичній науці вже доведено, що активізація варіантних різнорівневих мовних явищ відбувається на межі певних синхронних періодів. У своїх дослідженнях В.Н. Ярцева (1990), покликаючись на праці А.Ю. Русакова, зазначає: "Варіативність $є$ підгрунтям (точкою), у якому здійснюється синтез традиційної синхронної й діахронної лінгвістики” (с. 119). Мова ніби сама, до того ж під впливом різних суспільних і лінгвальних чинників, висуває такий собі широкоаспектний прошарок - варіантність, який поєднує синхронні відтинки й діахронію. В.Н. Ярцева (1990) досить влучно характеризує суть варіантності: “Саме варіювання слугує для подолання розриву між синхронією та діахронією” (с. 119). Морфологічну варіантність, на думку цієї дослідниці, можна виявити на основі морфемного аналізу (с. 119).

Розвиток морфологічної варіантності засвідчує також поява нових фемінативів на означення осіб жіночої статі за родом діяльності чи професійним спрямуванням. Ця тенденція - не нова, вона розпочалася майже десять років тому. Ініціював уживання фемінативів, як і чимало інших варіантних явищ, телеканал СТБ, підхопили цю практику Студія 1+1, ICTV, а також молоді, менш рейтингові українські телеканали 112 Україна, 24 канал, Еспресо TV, NewsOne. Попри те, що в мові телебачення фемінативи вживають непослідовно, тенденція набула виразності, про що свідчать фрагменти мововжитку останніх часів: його Валентина, тод $i$ - волонтерка 
(СТБ, Вікна, 17.02 .2017 р., 18.00, журналістка); канщлерка неоднозначно поглянула в його бік (112 Україна, Новини, 18.03.2017р., 13.10, ведучий); лейтенантка несе службу на рівні інших (СТБ, Вікна, 12.12 .2016 р., 18.00, журналіст); бой-френд відомої ді-джейки (24 канал, Вєсті UA, 16.02.2017р., 12.30, ведучий); коняківські майстрині (ICTV, Факти, 10.02.2017 р., 18.45, журналістка); найкраща композиторка Богдана Фроляк (Студія 1+1, ТСН, 20.02.2017 р., 19.30, ведуча); неофіційна нарада за участі прем'єрки (112 Україна, Новини, 23.05.2017 р., 07.00, ведуча); як не пригадати і партнерку Лесика - дівчинку Лесю (24 канал, Згадати все, 15.04.2017 р., 14.30, голос ведучого за кадром); знавчиня слова (Еспресо TV, Студія, 14.02.2017 р., 12.15, ведуча); Мімель називає бабияю “пані професорка” (24 канал, Наші, 16.02.2017 р., 12.45, голос ведучої за кадром); Ганна - психологиня (СТБ, Вікна, 12.12.2016 р., 18.00, журналістка).

Варто відзначити, що в сучасному українському мовознавстві (і в суспільстві загалом) ставлення до фемінативів не однозначне. Одні з науковців (О.О. Тараненко, А.М. Архангельська та ін.) відверто не сприймають таких новотворів, як психологиня, філологиня, професорка, деканка, знавчиня, інші (М.Д. Гінзбург, А. М.Нелюба, С.П. Семенюк та ін.) - навпаки, стають на захист фемінативів, аргументуючи тим, що вони типові для української мови і властиві їй здавна. А.М. Архангельська (2014) критично оцінює мовну політику ЗМІ, які переконують: чим більше таких “найчудніше уклепаних” (І. Верхратський) слів уживають український мовець i “мовкиня” vs. “мовчиня”, то більш шляхетним і українським є їхнє мовлення. Смак доби притупляє усвідомлення того, що “українська мова $є$ настільки особливе та естетично пригоже явище, що його не можна руйнувати своєю необережністю та байдужістю (Ї. Марван)" (Архангельська, 2014, с. 68). Натомість Є.А. Карпіловська (2007) наголошує, що серед фемінативів $\epsilon$ такі, “які не суперечать системі та структурі української мови і які засвідчені авторитетними кодифікаційними джерелами як стилістично нейтральні (асистентка, дисертантка, дослідниия, пасажирка, бібліотекарка)" (с. 68), а тому, оцінюючи такі інновації, потрібно враховувати “чинник естетичної сприйнятності новоутвореного слова (Г.М. Сюта)” (Карпіловська, 2007, с. 68). Отже, дискусія про органічність/неорганічність фемінативів триває не лише серед користувачів мови, а й серед її дослідників.

Розглянемо фемінативи як варіанти родової категоризації іменників. Варіантність морфологограматичних формальних показників таких слів зумовлена наявністю різних потенційних моделей словотворення, зокрема форм із суфіксом -к- (-a) та суфіксом -uн'- (a). Г. І. Лиса (2015) зазначає: “Неусталеність моделей творення фемінативів різними способами спричинює варіантність форм” (с. 289). Яскравим прикладом таких варіантних пар в українській мові $є$ усталена й семантично тотожна пара господиня - господарка. За аналогією до неї в сучасному телевізійному мовленні утворено канилерка - канилеркиня, переважно в розмовному мовленні: членка - членкиня, свинарка - свинаркиня. Однак зауважимо: якщо нормативні господиня господарка є сталими в мовному узусі, кодифікованими в лексикографічних джерелах, зокрема в СУМі (СУМ, 1970-1980, ст. 140, 142), то канилерка - канилеркиня, членка - членкиня та інші, утворені за різними моделями чи просто одиничні, як-от: синоптикиня (синоптикеса), борчиня (борчиха), психологиня, професориня) - поки що не зафіксовані у словниках. Те саме можна сказати й про номінації професорка (професориня), психологиня, які донині вважалися ненормативними з позиції кодифікації в академічних словникарських працях, однак у деяких новітніх сучасних словниках вже представлені (Лиса, 2015). Іншими словами, в межах граматичної категорії роду такі іменники, як професорка (= професор- особа жіночої статі), психологиня ( = психолог - особа жіночої статі) виявляють тенденцію до претендування на роль варіантних, оскільки вже є подекуди закріплені в словниках, хоч і новітніх. Чинні ж узуальні норми декан, професор, філолог, психолог, які стосуються осіб жіночої статі за професійним спрямуванням чи певним родом діяльності, хоч і мають формально-граматичний показник чоловічого роду на означення назв осіб за родом професійної діяльності, не потребують 
морфемного вираження ознак жіночого роду, тобто суфікс у таких назвах жіночої статі виконує тільки граматичну функцію, служить для позначення родової грамеми, як справедливо зазначає Г. І. Лиса $(2015$, с. 288).

Висновки й перспективи подальших досліджень. Підбиваючи підсумки, зазначимо, що в сучасних українських телемедіа внаслідок певних екстралінгвальних (більшою мірою) та інтралінгвальних причин активізовано мовні тенденції до варіантного вияву в межах морфолого-граматичної категорії роду, а саме уживання форм чоловічого роду замість форм жіночого і навпаки. Чимало варіантів мають ознаки питомих, рідковживаних чи відроджених номінацій, хоча більшість 3 аналізованих морфологічних одиниць - запозичення з інших мов. Аналіз лексикографічних джерел засвідчив, що чималу кількість протиставлених за родовою ознакою номінацій (зал-зала, сусід - сусіда, мотузок-мотузка, сховок-схованка) зафіксовано в словниках сучасної української мови, що дає підстави для висновку про варіантність нормативних форм родової категоризації іменника.

Водночас широке коло некодифікованих варіантів родової категоризації іменників свідчить, 3 одного боку, про порушення чинних норм, а з іншого - означає розвиток мовної системи, пошук ЗМІ зручних актуальних мовних форм.

Надалі плануємо дослідити варіантність інших граматичних категорій іменника.

\section{ЛІТЕРАТУРА}

Архангельська, А. М. (2014). До проблеми словотвірної фемінізації в українській мові новітньої доби: традиція і сучасність. II. Мовознавство. 1, 58-70. Київ.

Ахманова, О. С. (1957). Очерки по общей и русской лексикологии. Москва.

Вихованець, I. Р. (2004). Теоретична морфологія украӥнськоӥ мови: Акад. граматика укр. мови (За ред. І.Вихованця). Київ: Унів. вид-во “Пульсари”.

Горбачевич, К. С. (1971). Изменение норм русского литературного языка. Ленінград: Просвещение.

Карпіловська, С. А. (2007). Тенденції розвитку сучасного українського лексикону: чинники стабілізації інновацій. Українська мова. 4, 3-15. Київ

Карп’юк, М. Д. (1978). “Паралельна форма”, “дублет” чи “варіант”? Культура слова. Вип. 15, 70-75. Київ.

Лиса, Г. І. (2015). Динаміка сучасної родової категоризації іменника та ï лексикографічна інтерпретація. Науковий вісник кафедри Юнеско КНЛУ. Серія Філологія. Педагогіка. Психологія. Випуск 31, 287-294. Київ.

Матвіяс, І. Г. (1974). Іменник в украӥнській мові. Київ: Радянська Школа.

Поставний, В.В. (1974). Морфологічні варіанти іменників. Украӥнська мова і література в школі. 8, 35-44.

Родніна, Л. О. (1963). Про морфологічні варіанти іменників у сучасній українській мові. Дослідження з мовознавства. Вип. 2, 52-61. Київ.

Семенюк, С. (2007). Формування словотвірної підсистеми фемінітивів до чоловічих особових назв за соціальним станом у новій українській мові. Українська мова. 4, 65-76. Київ.

Стишов, О. А. (2005). Українська лексика кінця ХХ століття: (На матеріалі мови засобів масової інформаиії). Київ: Пугач.

Тараненко, О. О. (2015). Актуалізовані моделі в системі словотворення сучасної української мови (кінець XX-початок XXI cm.). К.: Видавничий дім Дмитра Бураго.

Шевельов, Ю. (2002). Історична фонологія української мови. С. Вакуленко, А. Даниленко (пер. 3 англ.). Канад. інститут українських студій. Східний інститут українознавства ім. Ковальських, Харківське історико-філологічне товариство. Харків: Акта.

Ярцева, В. Н. (1990). Языки мира: проблемы языковой вариативности. Москва: Наука. 


\section{ЛЕКСИКОГРАФІЧНІ ДЖЕРЕЛА}

ЕСУМ - Етимологічний словник української мови: В 6 т. / [редкол.: О. С. Мельничук та ін.]. К.: Наукова думка, 1982-1989. - Т. 1-6.

СУМ - Словник української мови: в 11 тт. / АН УРСР. Ін-т мовознавства; за ред. І. К. Білодіда. К.: Наукова думка, 1970-1980.

СУМ - Словник української мови в 20 тт. / Національна академія України української мови. Інформ. Центр. - К., 2013. - Том 4.

Словарь української мови: В 4 т. / [упорядник: Борис Грінченко]. - К.: Редакція журнала “Кіевская Старина", 1908. - Т. 1-4.

СОСум - Сучасний орфографічний словник української мови: 180 тис. слів / Уклад.: В. В. Дубічинський, Н.Я. Косенко. - Х.: ВД “Школа”, 2009. - 1024 с.

Українська мова: Енциклопедія / [редкол.: Русанівський В.М., Тараненко О.О., (співголови), Зяблюк М.П. та ін. - К.: Укр. Енцикл., 2000. ? 752 с.].

УРСС - Українсько-російський словотворчий словник / за ред. 3.С. Сікорської. - 2-ге вид., перероб. і допов. Словник. К.: Освіта, 1995. - 256 с.

ДЖЕРЕЛО ІЛЮСТРАТИВНОГО МАТЕРІАЛУ

Коцюбинський, М. (1979). Твори в трьох томах. Том другий. Оповідання (1901-1909). К.: Видавництво художньої літератури “Дніпро”.

\section{REFERENCES}

Arkhangel's' ka, A. M. (2014). Do problemy' slovotvirnoyi feminizaciyi v ukrayins 'kij movi novitn 'oyi doby`: trady`ciya i suchasnist'. II. Movoznavstvo. 1, 58-70. Ky'yiv.

Axmanova, O. S. (1957). Ocherky` po obshhej y` russkoj leksy 'kology`y'. Moskva.

Vy'xovanecz', I. R. (2004). Teorety'chna morfologiya ukrayins 'koyi movy': Akad. gramaty 'ka ukr. movy' (Za red. I.Vy'xovancya). Ky'yiv: Univ. Vy'd-vo "Pul'sary"”.

Gorbachevy'ch, K. S. (1971). Y'zmeneny’e norm russkogo ly`teraturnogo yazыka. Leningrad: Prosveshheny'e.

Karpilovs'ka, Ye. A. (2007). Tendenciyi rozvy`tku suchasnogo ukrayins`kogo leksy 'konu: chy`nny 'ky’ stabilizaciyi innovacij. Ukrayins'ka mova. 4, 3-15. Ky'yiv.

Karp'yuk, M. D. (1978). "Paralel'na forma”, “dublet” chy“ “variant”? Kul'tura slova. Vy`p. 15, 70-75. Ky'yiv.

Ly`sa, G. I. (2015). Dy’namika suchasnoyi rodovoyi kategory zaciyi imenny'ka ta yiyi leksy’kografichna interpretaciya. Naukovy`j visny’k kafedry` Yunesko KNLU. Seriya Filologiya. Pedagogika. Psy`xologiya. Vy`pusk 31, 287-294. Ky’yiv.

Matviyas, I. G. (1974). Imenny`k v ukrayins`kij movi. Ky`yiv: Radyans`ka Shkola.

Postavny `j, V.V. (1974). Morfologichni varianty` imenny kiv. Ukrayins'ka mova i literatura v shkoli. $8,35-44$.

Rodnina, L. O. (1963). Pro morfologichni varianty` imenny 'kiv u suchasnij ukrayins`kij movi. Doslidzhennya z movoznavstva. Vy’p. 2, 52-61. Ky'yiv.

Semenyuk, S. (2007). Formuvannya slovotvirnoyi pidsy`stemy` feminity'viv do cholovichy`x osobovy`x nazv za social’ny`m stanom u novij ukrayins`kij movi. Ukrayins`ka mova. 4, 65-76. Ky`yiv.

Sty'shov, O. A. (2005). Ukrayins'ka leksy 'ka kincya XX stolittya: (Na materiali movy` zasobiv masovoyi informaciyi). Ky'yiv: Pugach.

Taranenko, O. O. (2015). Aktualizovani modeli v sy'stemi slovotvorennya suchasnoyi ukrayins 'koyi movy` (kinecz` XX - pochatok XXI st.). K.: Vy`davny`chy`j dim Dmy`tra Burago.

Shevel'ov, Yu. (2002). Istory 'chna fonologiya ukrayins 'koyi movy'. S. Vakulenko, A. Dany'lenko (per. $\mathrm{z}$ angl.). Kanad. insty'tut ukrayins 'ky'x studij. Sxidny'j insty 'tut ukrayinoznavstva im. Koval's 'ky`x, Xarkivs `ke istory`ko-filologichne tovary’stvo. Kharkiv: Akta. 
Yarceva, V. N. (1990). Yazыky` my`ra: problemy yazыkovoj vary`aty`vnosty`. Moskva: Nauka. ESUM - Ety 'mologichny`j slovny'k ukrayins'koyi movy': V 6 t. / [redkol.: O. S. Mel'ny'chuk ta in.]. K.: Naukova dumka, 1982-1989. - T. 1-6.

SUM - Slovny`k ukrayins `koyi movy`: v 11 tt. / AN URSR. Insty`tut movoznavstva; za red. I. K. Bilodida. - K.: Naukova dumka, 1970-1980.

SUM - Slovny'k ukrayins 'koyi movy` v 20 tt. / Nacional'na akademiya Ukrayiny` ukrayins 'koyi movy”. - Inform. Centr. - K., 2013. - Tom 4.

Slovar` ukrayins`koyi movy`: V 4 t. / [uporyadny'k: Bory`s Grinchenko]. - K.: Redakciya zhurnala "Kievskaya Stary`na", 1908. - T. 1-4.

SOSum - Suchasny`j orfografichny`j slovny`k ukrayins`koyi movy`: 180 ty`s. sliv / Uklad.: V.V. Dubichy`ns'ky'j, N.Ya. Kosenko. - X.: VD "Shkola”, 2009. - 1024 s.

Ukrayins`ka mova: Ency'klopediya / [redkol.: Rusanivs`ky`j V.M., Taranenko O.O., (spivgolovy'), Zyablyuk M.P. ta in. - K.: Ukr. Ency'kl., 2000. - 752 s.].

URSS - Ukrayins `ko-rosijs `ky`j slovotvorchy`j slovny`k / za red. Z.S. Sikors`koyi. - 2-ge vy`d., pererob. i dopov. Slovny'k. K.: Osvita, 1995. - $256 \mathrm{~s}$.

Kocyuby`ns`ky`j, M. (1979). Tvory`v tr’ox tomax. Tom drugy`j. Opovidannya (1901-1909). K.: Vy'davny'cztvo xudozhn'oyi literatury' "Dnipro".

Дата надходження до редакиіï 22.02.2018 p. Ухвалено до друку 27.04.2018 р. 